\title{
ANALISA SPASIAL MENGGUNAKAN SISTEM INFORMASI GEOGRAFIS UNTUK IDENTIFIKASI PENYERAPAN RUANG TERBUKA HIJAU TERHADAP EMISI KARBONDIOKSIDA
}

\author{
Rachmad Ary Ramadhan ${ }^{1}$, Anik Vega Vitianingsih ${ }^{2 *}$, Yunus Susilo ${ }^{3}$, Anastasia Lidya \\ Maukar $^{4}$, Erri Wahyu Puspitarini ${ }^{5}$ \\ 1,2 Teknik Informatika, Universitas Dr. Soetomo, Surabaya, Indonesia \\ ${ }^{3}$ Teknik Geomatika, Universitas Dr. Soetomo, Surabaaya, Indonesia \\ ${ }^{4}$ Industrial Engineering Department, President University, Bekasi, Indonesia \\ ${ }^{5}$ Teknik Informatika, STMIK Yadika Bangil, Pasuruan, Indonesia \\ e-mail: rachmad.ary1@gmail.com ${ }^{1}$, vega@unitomo.ac.id ${ }^{2^{*}}$, yunus.susilo@unitomo.ac.id ${ }^{3}$, \\ almaukar@gmail.com ${ }^{4}$,www.erri@stmik-yadika.ac.id ${ }^{5}$
}

\begin{abstract}
Abstrak
Perubahan iklim dapat mengakibatkan dampak negatif pada lingkungan. Penyebab salah satunya merupakan pemanasan global, yaitu meningkatkatnya emisi karbondioksida (CO2). Penelitian ini menggunakan teknolgi Sistem Infromasi Geografis (SIG) dalam melakukan Analisa untuk identifikasi penyerapan ruang terbuka hijau (RTH) terhadap massa emisi CO2 dengan status rendah, sedang dan tinggi. Metode Box Model digunakan untuk proses Analisa spasial tersebut berdasarkan parameter kegiatan industri, konsumsi bahan bakar, pemakaian LPG, peternakan, tumpukan sampah dan respirasi manusia. Laju serapan terhadap emisi CO2 pada RTH dikategorikan pada klas cukup RTH dan kurang RTH. Hasil uji menggunakan Cohen's Kappa menghasilkan koefisien rata-rata 0.41 , sehingga dapat disimpulkan bahwa Box Model dan daya serap terhadap emisi $\mathrm{CO} 2$ memiliki tingkat cukup kategori kekuatan kesepakatan untuk digunakan dalam pemodelan data spasial.
\end{abstract}

Kata kunci: SIG Analisa Spasial, Box Model, Daya Serap RTH, Emisi CO2, Guttman Scale, Cohen's Kappa

\begin{abstract}
Climate change can have a negative impact on the environment. One of the causes is global warming, namely the increase in carbon dioxide (CO2) emissions. This research uses Geographic Information System (GIS) technology in conducting analysis to identify the absorption of green open space (RTH) on the mass of $\mathrm{CO} 2$ emissions with low, medium and high status. The Box Model method is used for the spatial analysis process based on the parameters of industrial activities, fuel consumption, LPG consumption, livestock, garbage piles and human respiration. The rate of absorption of $\mathrm{CO} 2$ emissions in green open space is categorized in the sufficient green open space class and less green open space. The test results using Cohen's Kappa produce an average coefficient of 0.41 , so it can be concluded that the Box Model and absorption capacity for $\mathrm{CO} 2$ emissions have a sufficient level of agreement strength category to be used in spatial data modeling.
\end{abstract}

Keywords : GIS Spatial Analysis, Box Model, Green Space Absorption, CO2 Emissions, Guttman Scale, Cohen's Kappa

Diterima Redaksi: 16-01-2021 | Selesai Revisi: 02-07-2021 | Diterbitkan Online: 31-07-2021 DOI: https://doi.org/10.23887/janapati.v10i2.30007

\section{PENDAHULUAN}

Perubahan iklim mengakibatkan dampak negatif pada lingkungan. Salah satu dampak dari pemanasan global, yaitu meningkatnya suhu atmosfer. Salah satu dari pemanasan global adalah meningkatkatnya karbondioksida (CO2). Inventarisasi Gas Rumah Kaca (GRK) Indonesia pada sektor energy mencapai 261,89 juta ton CO2 pada tahun 2015[1].

Kabupaten Sidoarjo merupakan daerah yang mengalami perkembangan pesat salah satunya pada bidang industri dan perdagangan. Perkembangan perekonomian dapat mempengaruhi bertambahnya penduduk di Kabupaten Sidoarjo yang dapat mengakibatkan 
perubahan pada lingkungan[2]. Perubahan pada lingkungan dapat mengakibatkan pengaruh buruk, apalagi jika sebelumnya pemerintah belum ada perencanaan untuk mengantisipasi perubahan terhadap pengelolaan lingkungan hidup kawasan perkotaan. Permasalahan lingkungan ditimbulkan oleh pertumbuhan penduduk membuat meningkatnya kawasan untuk pemukiman, yang mempengaruhi jumlah emisi $\mathrm{CO} 2$ yang dihasilkan bertambah serta kawasan hijau sebagai daya dukung lingkungan dapat berkurang.

Emisi CO2 merupakan gas rumah kaca yang dapat menyebabkan pemanasan global[3]. Gas rumah kaca disebabkan pantulan sinar UV oleh lapisan gas rumah kaca yang kemudian di biaskan oleh bumi. Akibat sinar UV yang dipantulkan tersebut menyebabkan bumi semakin panas, sehingga membuat naik permukaan laut karena dapat mencairkan es di kutub selatan dan kutub utara.

Ruang terbuka hijau memiliki manfaat terhadap struktur, yaitu keseimbangan, kesehatan, kenyamanan, kelestarian, peningkatan, dan kelangsungan kualitas lingkungan. Kelebihan ruang terbuka hijau juga mampu menyerap emisi $\mathrm{CO} 2$ yang dihasilkan dari segala aktivitas yang terjadi di Kabupaten Sidoarjo[4]. Ruang terbuka hijau minimal luasan $30 \%$ dari luas keseluruhan [5].

Pemodelan data spasial merupakan proses spasial data hasil analisis untuk menentukan keputusan dan kebijakan pemangku kepentingan. Proses yang dihasilkan termasuk geocoding dan pemetaan untuk menghasilkan sistem pengambilan keputusan [6] melalui penerapan Artificial Intellegence (AI)[7][8][9]. Sistem informasi geografis merupakan sistem berbasis teknologi yang digunakan untuk memanipulasi dan menyimpan informasi geografis[10]. Istilah "geografis" memiliki pengertian mengenai bumi, suatu kesatuan formal yang terdiri dari objek-objek yang terdapat di permukaan bumi[11].

Penelitian sebelumnya menggunakan data spasial dan statistik perkotaan digunakan untuk mengeksplorasi di dalam dan di luar sistem kota $\mathrm{CO} 2$ dan memperkirakan jumlah emisi $\mathrm{CO} 2$ dari lalu lintas jalan raya, penggunaan listrik dan gas di gedung, dan jumlah CO2 yang diserap oleh ruang hijau dan badan air di dalamnya dikembangkan melalui SIG[12]. Model praktis untuk keputusan lokasi stasiun pengisian yang menggabungkan SIG dengan metode MultiCriteria Decision Making (MCDM), tahap ini difokuskan pada arus lalu lintas dan distribusi jalan[13]. Analisis emisi CO2 yang dihasilkan oleh konsumsi energi/bahan bakar yang dihitung adalah emisi dari kegiatan yang dikontrol penuh oleh perusaaan yaitu penggunaan boiler (bahan bakar solar industri), penggunaan mobil operasional (bahan bakar solar) dan pengoperasioan motor operasional (bahan bakar bensin), emisi $\mathrm{CO} 2$ dari penggunaan listrik dan daya serap $\mathrm{CO} 2$ dengan ruang terbuka hijau[14]. Analisis emisi $\mathrm{CO} 2$ dari penggunaan bahan bakar sektor transportasi, industri, dan pemukiman menggunakan Box Model dan analisis daya serap RTH publik[15]. Pembangunan ruang terbuka hijau diperlukan sebagai penyeimbang emisi gas $\mathrm{CO} 2$ dari aktivitas penduduk dan konsumsi bahan bakar kendaraan, untuk menganalisis luasan RTH dan kemampuan serap CO2 serta besarnya emisi CO2 yang dilepaskan oleh aktivitas respirasi dan penggunaan bahan bakar minyak[16]. However, penelitian yang telah dilakukan belum menggunakan parameter yang akan diusulkan dipembahasan makalah ini, dengan parameter emisi CO2 kegiatan industri, konsumsi bahan bakar kendaraan, penggunaan LPG, peternakan, tumpukkan sampah, dan respirasi manusia dan analisa penyerapan daya serap CO2 dengan ruang terbuka hijau.

Tujuan dari pembahasan paper ini untuk mengetahui kemampuan daya serap $\mathrm{CO} 2$ yang dihasilkan dari RTH dan jumlah emisi $\mathrm{CO} 2$ yang dihasilkan berdasarkan kegiatan industri, konsumsi bahan bakar kendaraan, penggunaan LPG, peternakan, tumpukkan sampah, dan respirasi manusia dengan menggunakan metode Box Model dan klasifikasi tinggi, sedang, rendah dengan skala Guttman.

\section{HASIL DAN PEMBAHASAN}

Spasial dataset pada Tabel 1 meliputi emisi $\mathrm{CO} 2$ berdasarkan hasil perhitungan dari seluruh kecamatan di Kabupaten Sidoarjo yang terdiri 18 Kecamatan meliputi kegiatan industri, konsumsi bahan bakar, penggunaan LPG, peternakan, tumpukkan sampah, dan respirasi manusia yang kemudian dihitung menggunakan Box Model untuk mencari laju massa emisi $\mathrm{CO} 2$ serta kemampuan daya serap $\mathrm{CO} 2$ berdasarkan luas ruang terbuka hijau dan laju serapan vegetasi. Perolehan data-data yang dibutuhkan didapat dari dinas terkait yaitu Badan Perencanaan Pembangunan Daerah (BPPD), Bapan Pusat Statistik (BPS), Dinas Perindustrian dan Perdagangan (DISPERINDANG), Dinas Perhubungan (DISHUB), Pertamina, Dinas Lingkungan Hidup dan Kebersihan (DLHK) Kabupaten Sidoarjo serta dari sumber website BMKG Juanda yang ditunjukkan pada Tabel 1. 
Tabel 1. Perolehan data dan data atribut

\begin{tabular}{|c|c|c|}
\hline No & Data Atribut & Sumber \\
\hline 1. & $\begin{array}{l}\text { Peta Kabupaten Sidoarjo dan Land Use Kabupaten } \\
\text { Sidoarjo }\end{array}$ & $\begin{array}{l}\text { Badan Perencanaan Pembangunan } \\
\text { Daerah Kabupaten Sidoarjo }\end{array}$ \\
\hline 2. & $\begin{array}{l}\text { Luas, jumlah, dan status kecamatan Kabupaten } \\
\text { Sidoarjo, Jumlah rumah tangga, Jumlah dan jenis ternak }\end{array}$ & $\begin{array}{lll}\text { Badan Pusat } & \text { Statistik Kabupaten } \\
\text { Sidoarjo } & & \end{array}$ \\
\hline 3. & $\begin{array}{l}\text { Jumlah dan jenis industry, Pemakaian bahan bakar tiap } \\
\text { industri }\end{array}$ & Dinas Perindustrian dan Perdagangan \\
\hline 4. & $\begin{array}{l}\text { Jumlah dan jenis kendaraan, jumlah pemakaian BBM } \\
\text { sektor transportasi }\end{array}$ & $\begin{array}{l}\text { Dinas Perhubungan, } \\
\text { Kabupaten Sidoarjo }\end{array}$ \\
\hline 5. & $\begin{array}{l}\text { Jumlah berat sampah, Jumlah, lokasi, dan luas RTH } \\
\text { publik }\end{array}$ & $\begin{array}{l}\text { Dinas Lingkungan Hidup } \\
\text { Kebersihan }\end{array}$ \\
\hline 6. & $\begin{array}{l}\text { Data kemampuan serapan } \mathrm{CO}_{2} \text { tanaman dan intensitas } \\
\text { cahaya }\end{array}$ & Studi Literatur \\
\hline 7. & Arah dan kecepatan angin Kabupaten Sidoarjo & $\begin{array}{l}\text { BMKG } \\
\text { http://dataonline.bmkg.go.id/data_iklim }\end{array}$ \\
\hline
\end{tabular}

\section{METODE}

Tahapan proses dalam pemodelan data spasial untuk identifikasi penyerapan ruang terbuka hijau terhadap karbondioksida dengan Web-GIS ditunjukkan pada Gambar 1. Tahap ini memberikan gambaran sistem bekerja. Mulai dari memasukkan kebutuhan data, kemudian dilakukan proses pemodelan spasial data dengan metode yang cocok dengan perilaku data yang diperoleh dari pencatatan proses, bagian akhir adalah menampilkan hasil pemodelan data spasial sesuai dengan fungsi dan tujuan yang ingin dicapai dalam SIG[17].

Langkah pertama, pendefisian data spasial dan data atribut dalam spasial data set shapefile ( ${ }^{*}$. shp). Dataset tersebut mencakup peta Kabupaten Sidoarjo, emisi $\mathrm{CO}_{2}$ terdiri dari kegiatan industri, konsumsi bahan bakar kendaraan, pemakaian LPG, peternakan, tumpukan sampah, dan respirasi manusia serta kemampuan daya serap $\mathrm{CO} 2$ dari luas ruang terbuka hijau dan laju serap vegetasi data yang didapat pada Tabel 1. Kemudian diklasifikasikan menggunakan skala Guttman dengan 3 klasifikasi yaitu Tinggi, Sedang, dan Rendah. Hasil akhir akan dilakukan perbandingan hasil perhitungan emisi $\mathrm{CO}_{2}$ dengan daya serap $\mathrm{CO}_{2}$ yang kemudian dapat diketahui bahwa tiap wilayah kecamatan mana yang kekurangan ruang terbuka hijau dan perlu adanya penambahan ruang terbuka hijau di kecamatan yang kekurangan tersebut.

\section{A. Daya Serap RTH}

Menghitung kemampuan serapan RTH adalah dengan mengalikan laju serapan (S) dengan Luas RTH (LT) pada Persamaan (1)

$$
D S A=S \times L T
$$

dimana DSA adalah hasil perhitungan daya serap RTH per kecamatan yang didapatkan dari perkalian $(S)$ yang merupakan laju serapan $(S)$ dan $(L T)$ yang merupakan luas RTH. Nilai laju serapan $(S)$ diperoleh dengan Persamaan (2)

$$
S=0,2278 e^{(0,0048 \times I)}
$$

dimana $0,2278 e$ merupakan nilai euler dan $(0,0048 \times I)$ merupakan nilai intensitas cahaya.

a. Kegiatan industri, besarnya emisi $\mathrm{CO}_{2}$ dari kegiatan industri bergantung pada banyak dan jenis bahan bakar yang dibakar. Banyaknya bahan bakar direpresentasikan sebagai data aktivitas sedangkan jenis bahan bakar direpresentasikan oleh faktor emisi. Faktor emisi menurut IPCC dinyatakan dalam satuan emisi per unit energi yang dikonsumsi[14] pada Persamaan (6)

$K A=K E_{i} \times N K_{i} \times F E_{i}$

Dimana $K A$ merupakan total emisi $\mathrm{CO}_{2}$ dari kegiatan industri, $K E_{i}$ merupakan jumlah bahan bakar yang digunakan pertahun, $N K_{i}$ merupakan nilai kalor bahan bakar yang digunakan pertahun, $F E_{i}$ merupakan faktor emisi bahan bakar yang digunakan pertahun. Terdapat 4 jenis bahan bakar pada industri yaitu Bensin, Solar, LPG, dan Batubara yang dirumuskan pada Persamaan (7).

$K E_{a} \times N K_{a} \times F E_{a}$ $K E_{b} \times N K_{b} \times F E_{b}$ 
$K E_{c} \times N K_{c} \times F E_{c}$

$K E_{d} \times N K_{d} \times F E_{d}$

Dimana $K E_{a} \times N K_{a} \times F E_{a}$ untuk bahan bakar bensin, $K E_{b} \times N K_{b} \times F E_{b}$ untuk bahan bakar solar, $K E_{c} \times N K_{c} \times F E_{c}$ untuk bahan bakar LPG, dan $K E_{d} \times N K_{d} \times F E_{d}$ untuk bahan batubara.

b. Konsumsi bahan bakar kendaraan, emisi $\mathrm{CO}_{2}$ dari konsumsi bahan bakar kendaraan berdasarkan pembakaran bahan bakar penggunaan transportasi[18] pada Persamaan (8).

$K B=K E_{i} \times N K_{i} \times F E_{i}$

Dimana $K B$ merupakan total emisi $\mathrm{CO}_{2}$ dari konsumsi bahan bakar kendaraan. Terdapat 2 jenis bahan bakar pada transportasi yaitu Bensin dan Solar pada Persamaan (9).
$K E_{a} \times N K_{a} \times F E_{a}$

$K E_{b} \times N K_{b} \times F E_{b}$

Dimana $K E_{a} \times N K_{a} \times F E_{a}$ untuk bahan bakar bensin, $K E_{b} \times N K_{b} \times F E_{b}$ untuk bahan bakar solar.

c. Pemakaian LPG, emisi $\mathrm{CO}_{2}$ dari pemakaian LPG digunakan berdasarkan asumsi satu rumah tangga yang menghabiskan $9.15 \mathrm{~kg}$ sehari atau $109.8 \mathrm{~kg}$ setahun yang dikalikan dengan nilai kalor $N K$ dan faktor emisi $F E[18]$ pada Persamaan (10).

$K C=K E \times N K \times F E$

Dimana $K C$ merupakan total emisi $\mathrm{CO}_{2}$ dari pemakaian LPG

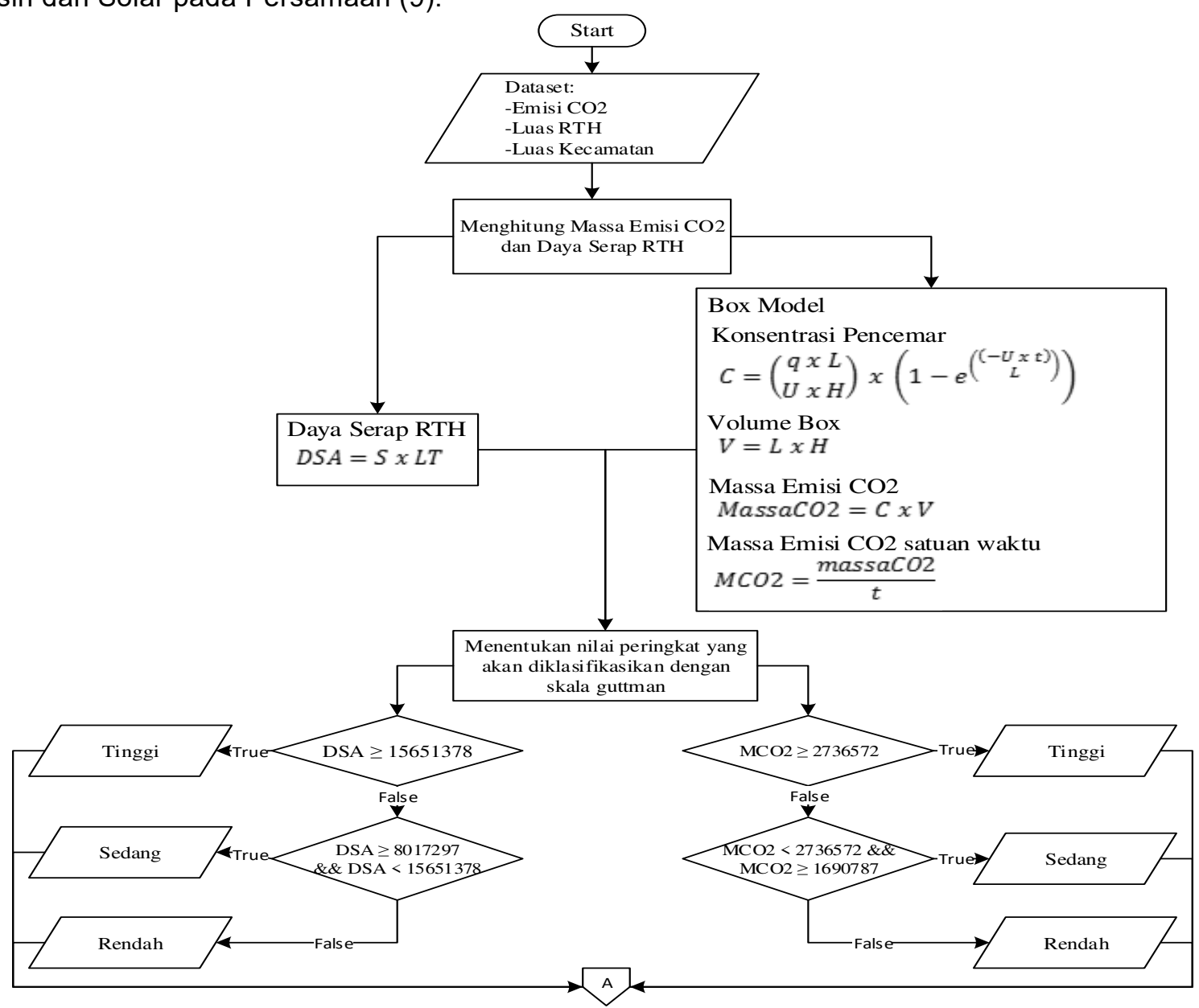

Gambar 1. Flowchart Box model dan daya serap RTH

d. Peternakan, emisi $\mathrm{CH}_{4}$ yang dihasilkan oleh hewan ternak pada saat proses fermentasi di dalam tubuh serta pada saat pengelolaan kotoran, yang kemudian akan diubah ke
Carbon Dioxide Equivalent $\left(\mathrm{CO}_{2} \mathrm{e}\right)$ dengan Global Warming Potential (GWP)[19]. Fermentasi enterik merupakan proses pemecahan molekul untuk diserap dalam darah[20] pada Persamaan (11). 
$K D=n_{i} \times F E_{i j} x K C O 2$

Dimana $K D$ merupakan total emisi $\mathrm{CO}_{2} \mathrm{e}$ dari peternakan, $n_{i j}$ jumlah hewan ternak, $F E_{i j}$ merupakan $F E_{i}$ untuk faktor emisi $\mathrm{CH}_{4}$ fermentasi enterik hewan ternak dan $F E_{j}$ untuk faktor emisi pengelolaan kotoran hewan ternak, dan $\mathrm{KCO} 2$ merupakan konversi dari emisi $\mathrm{CH} 4$ ke emisi $\mathrm{CO}_{2}$ sebesar 25. Terdapat 9 jenis hewan ternak dan faktor emisi pada Persamaan (12)

$n_{a} \times F E_{i j}$

$n_{b} x F E_{i j}$

$n_{c} \times F E_{i j}$

$n_{d} x F E_{i j}$

$n_{e} x F E_{i j}$

$n_{f} x F E_{i j}$

$n_{g} x F E_{i j}$

$n_{h} x F E_{i j}$

$n_{i} x F E_{i j}$

Dimana $n_{a}$ merupakan sapi perah, $n_{b}$ merupakan sapi potong, $n_{c}$ merupakan kerbau, $n_{d}$ merupakan kuda, $n_{e}$ merupakan kambing, $n_{f}$ merupakan domba, $n_{g}$ merupakan ayam buras, $n_{h}$ merupakan ayam petelur, $n_{i}$ merupakan ayam pedaging. Jenis dan jumlah ternak yang dimiliki Kabupaten Sidoarjo diambil dari data Sidoarjo dalam angka tahun 2019[2].

e. Tumpukan sampah, banyaknya tumpukan sampah dipengaruhi juga oleh pertumbuhan penduduk. Di tempat pembuangan akhir sampah menumpuk akan menghasilkan emisi $\mathrm{CH}_{4}$ [21]. Hasil perhitungan kemudian akan diubah ke Carbon Dioxide Equivalent $\left(\mathrm{CO}_{2} \mathrm{e}\right)[19]$ pada Persamaan (13).

$K E=B S \times F E x K C O 2$

Dimana $K F$ merupakan total emisi $\mathrm{CO}_{2} \mathrm{e}$ dari tumpukan sampah, $B S$ merupakan berat sampah individu per tahun, $F E$ merupakan faktor emisi sampah $\mathrm{CH} 4$ sebesar 0,004255 liter per $1 \mathrm{~kg}$ sampah.

f. Respirasi manusia dapat menghasilkan emisi $\mathrm{CO}_{2}[22]$ pada Persamaan (14)

$K F=n \times F E$

Dimana $K F$ merupakan hasil emisi $\mathrm{CO}_{2}$ dari respirasi manusia, $n$ merupakan jumlah penduduk per kecamatan, dan $F E$ merupakan faktor emisi dari respirasi manusia sebesar $0,9504 \mathrm{~kg}$ sehari atau 346,896 kg setahun.

1. Menghitung Volume Box yang dihitung berdasarkan Luas Kecamatan dan Tinggi Pohon $(H)$ pada Persamaan (15).
$V=$ Luas Kecamatan $x H$

Dimana $V$ merupakan hasil perkalian dari luas kecamatan dan tinggi pohon $(H)$.

2. Menentukan besar massa emisi $\mathrm{CO}_{2}$ pada Persamaan (16).

MassaCO2 $=C x \mathrm{~V}$

Dimana MassaCO2 merupakan besar massa emisi $\mathrm{CO}_{2}$ yang dihasilkan dari perkalian antara konsentrasi pencemar $(C)$ dan volume box $(V)$

3. Menentukan besar massa emisi $\mathbf{C O}_{2}$ dengan satuan waktu pada Persamaan (17).

$M C O 2=\frac{\text { massaCO2 }}{t}$

Dimana $\mathrm{MCO} 2$ merupakan besar massa emisi $\mathrm{CO}_{2}$ persatuan waktu yang dihasilkan berdasarkan MassaCO2 dibagi dengan waktu tempu $(t)$.

\section{Skala Guttman}

Skala Guttman merupakan pengukuran kesimpulan pada data kualitatif, dan digunakan untuk memberikan perkiraan nilai klasifikasi yang menghasilkan nilai intervensi yang masih ambigu karena ketidakpastian[23]. Nilai atau bobot dalam proses analisis, memberikan nilai berdasarkan faktor ketidakpastian kelas variabel yang dijelaskan dapat diukur menggunakan skala Guttman[17] di Persamaan 18.

$I=\frac{R}{K}$

Dimana I merupakan hasil dari nilai interval yang diperoleh dari variabel $R$, merupakan nilai data dan variabel $K$ merupakan jumlah alternatif klasifikasi yang akan dihasilkan.

Dalam penelitian ini, nilai variabel $R$ diperoleh dari nilai rentang nilai antara nilai maksimum dan minimum dari hasil emisi $\mathrm{CO}_{2}$ yaitu MCO2 dan daya serap RTH yaitu DSA. Variabel $K$ merupakan jumlah klasifikasi alternatif yaitu tinggi, sedang, dan rendah yang mengacu pada Gambar 1. Dan Tabel 2. Sedangkan, penentuan skala untuk menentukan klasifikasi wilayah daya serap RTH dan emisi $\mathrm{CO}_{2}$ digunakan Persamaan 19 untuk daya serap RTH dan Persamaan 20 untuk emisi $\mathrm{CO}_{2}$.

$\left\{\begin{array}{l}\text { Tinggi, if } D S A \geq 15651378 \\ \text { Sedang, if } D S A \geq 8017297 \text { AND }<15651378 \\ \text { Rendah, if } D S A<8017297\end{array}\right.$

(19) 
Tinggi, if MCO2 $\geq 2736572$

$\{$ Sedang, if MCO2 $\geq 1690787$ AND $<2736572$

Rendah, if MCO2 < 1690787

Tabel 2. Penilaian Skala Guttman

\begin{tabular}{|c|c|}
\hline Daya Serap RTH & Box Model \\
\hline $\begin{array}{c}R=D S A_{\text {maks }}-D S A_{\min }=23285459-383215 \\
=22902244\end{array}$ & $\begin{aligned} R=M C O 2_{\text {maks }}-M C O 2_{\min } & \\
= & 3782356-645002\end{aligned}$ \\
\hline$K=3$ & $=3137354$ \\
\hline$I=\frac{22902244}{3}=7634081$ & $\begin{array}{l}K=3 \\
I=\frac{3137354}{3}=1045785\end{array}$ \\
\hline
\end{tabular}

Penilaian kriteria Tinggi $=$ nilai tertinggi $-I=$ $23285459-7634081=15651378$

Penilaian kriteria Sedang $=$

nilai keriteria Tinggi $-I=15651378-7634081=$ 8017297
Penilaian kriteria Tinggi $=$ nilai tertinggi $I=3782356-1045785=2736572$

Penilaian kriteria Sedang $=$

nilai keriteria Tinggi $-I=2736572-$

$1045785=1690787$
Penilaian kriteria Rendah $=$

nilaileritoria Codano-I - 8017207-7621081Selanjutnya dilakukan perhitungan daya serap terhadap emisi $\mathrm{CO}_{2}$ pada Gambar 2 .

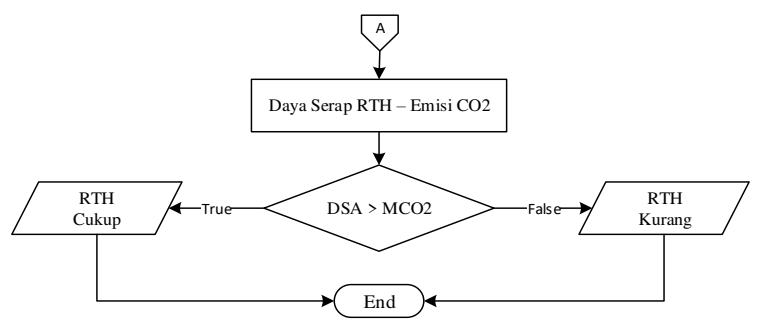

Gambar 2. Flowchart serapan $\mathrm{CO}_{2}$

\section{Serapan RTH}

Hasil akhir dari penelitian merupakan hasil perhitungan berdasarkan daya serap $\mathrm{RTH}$ terhadap emisi $\mathrm{CO}_{2}$ dengan penilaian pada Persamaan 19.

$$
\left\{\begin{array}{c}
\text { RTH Cukup, If DSA }>M C O 2 \\
R T H \text { Kurang, If DSA }<M C O 2
\end{array}\right.
$$

\section{E. Cohen's Kappa}

Metode uji konsistensi Cohen's Kappa digunakan untuk menguji konsistensi dalam mengukur dua metode atau dua penelitian. Pengukuran dapat dilakukan berdasarkan data kualitatif[24] pada Persamaan 20.

$K=\frac{P_{o}-P_{e}}{1-P_{e}}$

Dimana variabel $K$ merupakan koefisien hasil dari pengukuran antar penelitian. Variabel $P_{o}$
Penilaian kriteria Rendah $=$

nilai britoria Sodono-I - 1600787 merupakan kesepakatan relatif yang diamati di antara penilai dan variabel $P_{e}$ merupakan probalitas hipotesis kesepakatan kebetulan.

Rentang nilai koefisien dalam Cohen's Kappa yaitu variabel $K$, dimana jika $K<0.20$ merupakan rendah, $K=0,21-0,40$ merupakan lumayan, $K=0,41-0,60$ merupakan cukup, $K=0,61-0,80$ merupakan kuat, dan $K=$ $0,81-1,00$ merupakan sangat kuat.

\section{HASIL DAN PEMBAHASAN}

Hasil dari perhitungan yang telah dilakukan dari 18 kecamatan di Kabupaten Sidoarjo. Menggunakan Metode Box Model berdasarkan parameter emisi $\mathrm{CO}_{2}$ (kegiatan industri, konsumsi bahan bakar kendaraan, pemakaian LPG, peternakan, tumpukan sampah, dan respirasi manusia) dan daya serap RTH menggunakan kriteria klasifikafi tinggi, sedang, rendah ditunjukkan pada Gambar 3 dan Tabel 3 untuk daya serap RTH serta Gambar 4 Tabel 4 untuk emisi $\mathrm{CO}_{2}$. Sedangkan untuk hasil serapan $\mathrm{CO}_{2}$ ditunjukkan pada Gambar 5 dan Tabel 5. 


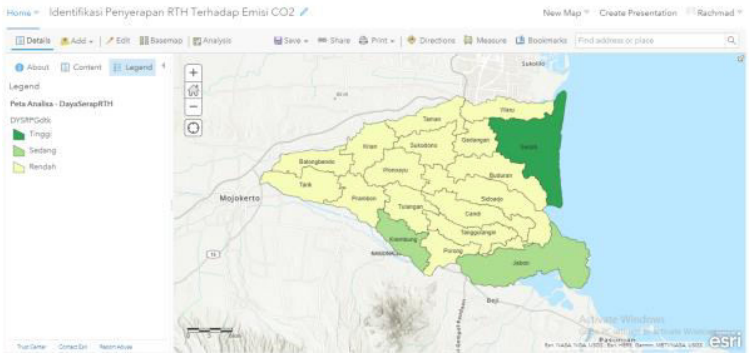

Gambar 3. Hasil daya serap RTH

Tabel 3. Hasil klasifikasi daya serap RTH

\begin{tabular}{ll}
\multicolumn{1}{c}{ Klass } & Jumlah Kecamatan \\
\hline Tinggi & 1 \\
Sedang & 2 \\
Rendah & 15 \\
\hline
\end{tabular}

Hasil daya serap RTH pada Tabel 3 dengan kriteria klasifikasi tinggi, sedang, rendah dihitung menggunakan Persamaan (1) menghitung luas RTH dengan laju serapan. Laju serapan RTH pada persamaan (2). Hasil daya serap RTH pada Gambar 3 didapat nilai tertinggi pada kecamatan Sedati 23285459 $\mathrm{Mg} / \mathrm{dtk}$. Sedangkan untuk terendah pada kecamatan Gedangan 383215.9 Mg/dtk.

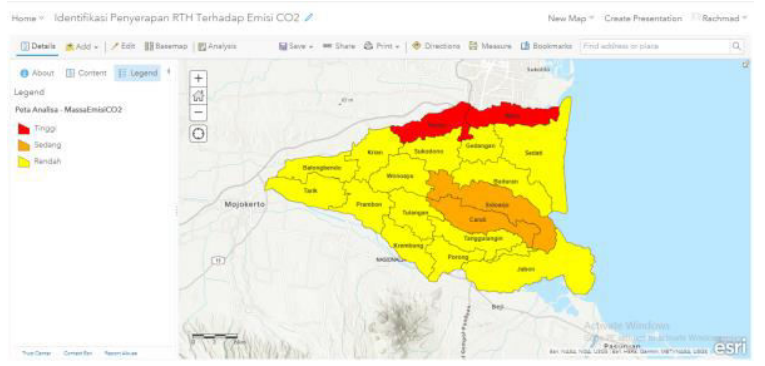

Gambar 4. Hasil emisi CO2 dengan Box Model

Tabel 4. Hasil klasifikasi emisi $\mathrm{CO}_{2}$

\begin{tabular}{ll}
\hline \multicolumn{1}{c}{ Klass } & Jumlah Kecamatan \\
\hline Tinggi & 2 \\
Sedang & 2 \\
Rendah & 14 \\
\hline
\end{tabular}

Hasil emisi $\mathrm{CO}_{2}$ pada Tabel 4 memiliki 2 kecamatan yang mendapatkan klasifikasi tinggi dengan nilai tertinggi pada kecamatan Waru $3782356 \mathrm{Mg} / \mathrm{dtk}$, 2 klasifikasi sedang, dan 14 kecamatan memiliki klasifikasi rendah dengan nilai terendah pada kecamatan Jabon 645002.5 $\mathrm{Mg} / \mathrm{dtk}$. Metode Box Model digunakan untuk mencari beban emisi $\mathrm{CO}_{2}$ dengan mencari konsentrasi pencemar $(C)$ pada Persamaan (3). Kontributor emisi ( $q$ ) digunakan untuk mencari emisi $\mathrm{CO}_{2}$ berdasarkan parameter kegiatan industri pada Persamaan (7) yaitu:

$K E_{\text {bensin }} \times N K_{\text {bensin }} \times F E_{\text {bensin }}$

$K E_{\text {solar }} \times N K_{\text {solar }} \times F E_{\text {solar }}$
$K E_{\text {lpg }} \times N K_{\text {lpg }} \times F E_{\text {lpg }}$

$K E_{\text {batubara }} \times N K_{\text {batubara }} \times F E_{\text {batubara }}$

Konsumsi bahan bakar kendaraan pada Persamaan (9) yaitu:

$K E_{\text {bensin }} \times N K_{\text {bensin }} \times F E_{\text {bensin }}$

$K E_{\text {solar }} \times N K_{\text {solar }} \times F E_{\text {solar }}$

Pemakaian LPG pada Persamaan (10), Peternakan yang menghasilkan emisi $\mathrm{CH}_{4}$ Persamaan (11) berdasarkan dari fermentasi enterik pada Persamaan (12) yaitu:

$n_{\text {sapi perah }} \times F E_{\text {enterik }}$

$n_{\text {sapi potong }} x F E_{\text {enterik }}$

$n_{\text {kerbau }} \times F E_{\text {enterik }}$

$n_{\text {kuda }} \times F E_{\text {enterik }}$

$n_{\text {kambing }} x F E_{\text {enterik }}$

$n_{\text {domba }} \times F E_{\text {enterik }}$

$n_{\text {ayam buras }} x F E_{\text {enterik }}$

$n_{\text {ayam petelur }} x F E_{\text {enterik }}$

$n_{\text {ayam pedaging }} x F E_{\text {enterik }}$

Dan pengelolaan kotoran:

$n_{\text {sapi perah }} \times F E_{\text {kotoran }}$

$n_{\text {sapi potong }} x F E_{\text {kotoran }}$

$n_{\text {kerbau }} \times F E_{\text {kotoran }}$

$n_{\text {kuda }} \times F E_{\text {kotoran }}$

$n_{\text {kambing }} x F E_{\text {kotoran }}$

$n_{\text {domba }} \times F E_{\text {kotoran }}$

$n_{\text {ayam buras }} x F E_{\text {kotoran }}$

$n_{\text {ayam petelur }} x F E_{\text {kotoran }}$

$n_{\text {ayam pedaging }} x F E_{\text {kotoran }}$

Tumpukkan sampah pada Persamaan (13) yaitu:

BS $x \mathrm{FE}_{\text {sampah }} \times \mathrm{KCO} 2$

Respirasi manusia pada Persamaan (14) yaitu:

banyak penduduk $x F E_{\text {manusia }}$

Setelah mendapatkan kontribusi emisi yang terkait dilanjutkan dengan menghitung Volume Box dengan Persaman (15). Besar massa emisi $\mathrm{CO}_{2}$ menggunakan Persamaan (16) dan menentukan besar massa emisi $\mathrm{CO}_{2}$ dengan satuan waktu pada Persamaan (17) sehingga dapat dihitung dengan laju serapan RTH.

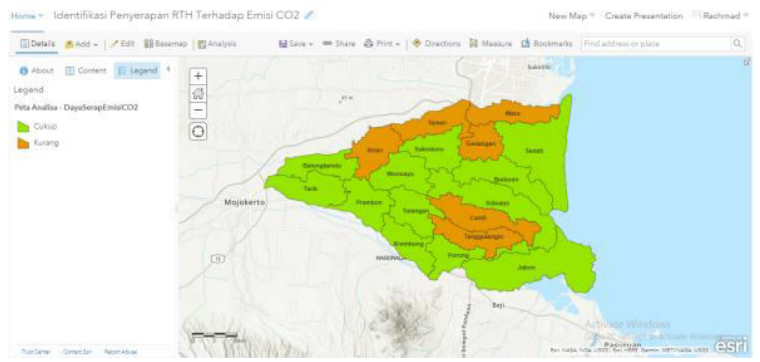

Gambar 5. Hasil Serapan $\mathrm{CO}_{2}$ 
Tabel 5. Hasil klasifikasi Serapan $\mathrm{CO}_{2}$

\begin{tabular}{ll}
\multicolumn{1}{c}{ Klass } & Jumlah Kecamatan \\
\hline Cukup RTH & 12 \\
Kurang RTH & 6 \\
\hline
\end{tabular}

Hasil serapan $\mathrm{CO}_{2}$ pada Tabel 5 menunjukkan bahwa Kabupaten Sidoarjo memiliki 6 kecamatan yang kekurangan RTH dan 12 kecamatan yang sudah memenuhi kecukupan RTH berdasarkan Persamaan (19) jika emisi $\mathrm{CO}_{2}$ melebihi daya serap RTH maka dikatakan kurang RTH dan jika emisi $\mathrm{CO}_{2}$ kurang dari daya serap RTH maka RTH dikatakan cukup.

\section{SIMPULAN DAN SARAN}

Hasil kesimpulan dengan metode Box Model dan serapan $\mathrm{CO}_{2}$ berdasarkan parameter emisi $\mathrm{CO}_{2}$ kegiatan industri, konsumsi bahan bakar kendaraan, pemakaian LPG, peternakan, tumpukan sampah, dan respirasi manusia serta daya serap RTH pada 18 wilayah kecamatan di Kabupaten Sidoarjo telah memberikan hasil perhitungan terdapat 12 kecamatan yang telah memenuhi kebutuhan RTH terhadap emisi $\mathrm{CO}_{2}$ dan 6 kecamatan yang belum memenuhi kebutuhan RTH berdasarkan sisa emisi $\mathrm{CO}_{2}$ melebihi serapan $\mathrm{CO}_{2}$ nya. Hasil uji validasi dengan Cohen's Kappa dengan penelitian sebelumnya yang memiliki hasil akhir yang sama, memiliki nilai yang menunjukkan keeratan kesepakatan Cukup dengan nilai 0,41. Pengembangan penelitian lebih lanjut yaitu perlu adanya penambahan daya serap berdasarkan jenis tanaman dan penambahan dari parameter emisi $\mathrm{CO}_{2}$ penggunaan listrik perumahan dan menggunakan metode beban emisi selain Box Model.

\section{REFERENSI}

[1] Kementerian Energi dan Sumber Daya Mineral, Data Inventory Emisi GRK Sektor Energi. Kementerian Energi dan Sumber Daya Mineral, 2016.

[2] Bapan Pusat Statistik Kabupaten Sidoarjo, Kabupaten Sidoarjo Dalam Angka 2019. Badan Pusat Statistik Kabupaten Sidoarjo, 2019.

[3] S. Sulistyono, "Pemanasan Global (Global Warming) dan Hubungannya Dengan Penggunaan Bahan Bakar Fosil," Swara Patra, 2012.

[4] Republik Indonesia, Peraturan Menteri Pekerjaan Umum Nomor:05/PRT/M/2008 tentang Pedoman Penyediaan dan Pemanfaatan Ruang Terbuka Hijau Di Kawasan Perkotaan. 2008.

[5] Republik Indonesia, Peraturan Menteri
Dalam Negeri Nomor 1 Tahun 2007 tentang Penataan Ruang Terbuka Hijau Kawasan Perkotaan. 2007.

[6] R. N. Parket and E. K. Asencio, G/S and Spatial Analysis for the Social Sciences Coding, Mapping, and Modeling. Routledge, 2008.

[7] S. Banerjee, B. P. Carlin, and A. E. Gelfand, Hierachical Modeling and Analysis for Spatial Data Second Edition. Taylor \& Francis Group, 2015.

[8] A. V. Vitianingsih, A. Choiron, D. Cahyono, A. Umam, and S. Suyanto, "Spatial data modeling on GIS for classification of measles-prone region using multiple attribute decision making," Int. J. Intell. Eng. Syst., vol. 12, no. 3, pp. 97-107, 2019.

[9] A. V. Vitianingsih, I. Wisnubhadra, S. S. K. Baharin, R. Marco, and A. L. Maukar, "Classification of pertussis vulnerable area with location analytics using multiple attribute decision making," Int. J. Innov. Comput. Inf. Control, vol. 16, no. 6, pp. 1943-1957, 2020.

[10] I. W. Krisna and E. Putra, "Sistem Informasi Geografis Untuk Prediksi Perkembangan Fisik Kota (Studi Kasus Kota SingarajaBali)," J. Nas. Pendidik. Tek. Inform., vol. 2, pp. 201-206, 2013.

[11] I. K. A. Paramarta, "Sistem Informasi Geografis Rencana Tata Ruang Wilayah (RTRW) Kabupaten Buleleng Berbasis Web," J. Nas. Pendidik. Tek. Inform., vol. 2, 2013.

[12] M. S. Alam, P. Duffy, B. Hyde, and A. McNabola, "Downscaling national road transport emission to street level: A case study in Dublin, Ireland," J. Clean. Prod., vol. 183, pp. 797-809, 2018.

[13] J. Zhou, Y. Wu, C. Wu, F. He, B. Zhang, and F. Liu, "A geographical information system based multi-criteria decisionmaking approach for location analysis and evaluation of urban photovoltaic charging station: A case study in Beijing," Energy Convers. Manag., vol. 205, no. August 2019, p. 112340, 2020.

[14] Purnomosutji, "Analisis ruang terbuka hijau terhadap penyerapan emisi karbondioksida," pp. 34-41, 2019.

[15] I. W. Murti, J. Hermana, and R. Boedisantoso, "Inventarisasi dan Penentuan Kemampuan Serapan Emisi CO2 oleh Ruang Terbuka Hijau di Kabupaten Sidoarjo, Jawa Timur," Pros. Semin. Nas. Manaj. Teknol. XXII Progr. Stud. MMT-ITS, p. A.50.1-A.50.6, 2015.

[16] Fuad Jaya Miharja, Husamah, and Tatag 
Muttaqin, "Analisis kebutuhan ruang terbuka hijau sebagai penyerap emisi gas karbon di kota dan kawasan penyangga Kota Malang," J. Pengelolaan Lingkung. Berkelanjutan, vol. 2, no. 3, pp. 165-174, 2018.

[17] A. V. Vitianingsih, A. Choiron, D. Cahyono, A. Umam, and Suyanto, "Spatial Data Modeling on GIS for Classification of Measles-prone Region Using Multiple Attribute Decision Making," Int. J. Intell. Eng. Syst., 2018.

[18] Kementerian Lingkungan Hidup, Pedoman Penyelenggaraan Inventarisasi Gas Rumah Kaca Nasional Buku I Pedoman Umum. Kementerian Lingkungan Hidup, 2012.

[19] M. Brander, "Greenhouse Gases , CO2 , CO2e , and Carbon: What Do All These Terms Mean?," Ecometrica, 2012.

[20] R. V. S. Weo, M. E. Bolla, and Y. A. Messah, "Analisis Ruas Jalan Rawan
Kecelakaan Lalulintas Menggunakan Sistem Informasi Geografis," J. Tek. Sipil, vol. IV, no. 2, pp. 133-146, 2015.

[21] R. P. R. Nur and H. Purnomo, "Model Simulasi Emisi dan Penyerapan CO 2 di Kota Bogor (Model Simulation of $\mathrm{CO} 2$ Emission and Absorption in Bogor City)," $J$. Ilmu Pertan. Indones., vol. 20, 2015.

[22] L. Suryaningsih, A. T. S. Haji, and R. Wirosoedarmo, "Jurnal sumberdaya alam dan lingkungan analisis spasial defisiensi ruang terbuka hijau (RTH) di Kota Mojokerto," J. Sumberd. Alam dan Lingkung., vol. 1, pp. 1-10, 2015.

[23] L. Guttman, "A Basis for Scaling Qualitative Data," Am. Sociol. Rev., vol. 9, 1944.

[24] R. Azen and C. M. Walker, Categorical Data Analysis for the Behavioral and Social Sciences. Taylor \& Francis Group, 2011. 